\title{
SELECTED FRAGMENTS OF ROAD CORRIDORS AS ENVIRONMENTAL BARRIERS
}

\author{
Jerzy Solon \\ Institute of Geography and Spatial Organization \\ Polish Academy of Sciences \\ Twarda St. 51/55, 00-818 Warsaw, Poland \\ j.solon@twarda.pan.pl
}

\begin{abstract}
In the case of the majority of roads built nowadays, the main environmental structural and functional effects include fragmentation of ecosystems and barriers to populations of many animal species. Specific objectives include the following: (a) to determine fragmentation of forest areas in the gminas which are traversed by selected transports routes and to define the role of these routes for an increasing landscape fragmentation; (b) to determine the number of traffic incidents involving animals by road categories, seasons, time of the day or night and distance from forest. For the detailed analyses six research areas were selected through which the selected road sections run: (a) A1 on section Pruszcz Gdański-Grudziądz (operational since 2008) and DK91; (b) A4 on section Wrocław-Opole (operational since 2003) and DK94; (c) DK8 on section Kudowa Zdrój-Wrocław; (d) DK8 on section Augustów-Budzisko; (e) DK17 on section Garwolin-Kurów; (f) S8 on section Radzymin-Wyszków. Data on traffic incidents which involved animals cover the years 2006-2012 and originate from the SEWIK database. The results obtained show that: (1) between 2006 and 2012 the number and percentage of incidents involving animals were increasing on a regular basis; (2) new roads (motorways and expressways) do not significantly enhance the value of formal landscape fragmentation indicators, but constitute tremendous physical barriers. It is proven, inter alia, by a visibly lower number and density (per $1 \mathrm{~km}$ of road) of incidents on these routes, compared to other roads; (3) there is no simple relation between landscape fragmentation and the number and location of forest patches on the one hand, and the total number of incidents and their distribution in space on the other; incidents involving animals take place mainly late in the evening and at night; (4) events occur more frequently $100 \mathrm{~m}$ away from the forest than at a distance of 100-200 m away, which may prove some preferences as to road crossing place selection by the animals; (5) incidents within built-up areas, especially during the daytime, have different seasonal pattern, in particular there are no pronounced minimum and maximum periods, which may prove that these incidents involve animals other than ungulates.
\end{abstract}

Key words: road corridors, environmental barriers, incidents involving animals, land fragmentation.

\section{Introduction}

Literature on the impact of roads on landscape and living organisms shows that in the case of the majority of roads built in modern times, the major structural and functional effects include the following: fragmentation of ecosystems and barriers to populations of many animal species (Forman 
\& Alexander 1998; Jędrzejewski et al. 2006; Jędrzejewska \& Jędrzejewski 2008; Morawska \& Żelazo 2008; Forman et al. 2009; Jaeger et al. 2011)1.

The traffic intensity is most important factor creating a psychophysical barrier. For medium and large land animals, it is assumed that in the case of roads without any special protection (nets, high barriers and screens) with the traffic intensity of about 6,000 vehicles per 24 hours up to $20 \%$ of animals attempting to cross the road are scared off, while with the traffic intensity exceeding 10,000 vehicles per 24 hours $70 \%$ of animals are scared off. The picture of death rates of animals crossing roads is different. With a traffic intensity of up to 1,000 vehicles per 24 hours the animal death rate does not exceed $20 \%$, with 2,500 vehicles it is about $50 \%$ and when traffic intensity exceeds 10,000 vehicles per 24 hours only 5\% of attempts of crossing are successful (Jędrzejewski et al. 2006; Kurek 2010b).

The general objective of this chapter is to assess the role of selected road sections as environmental barriers. Specific objectives include the following: (a) to determine fragmentation of forest areas in the gminas through which selected transports routes run and to define the role of these routes for an increasing landscape fragmentation; (b) to determine the number of traffic incidents involving animals by road categories, seasons, time of the day or night and distance from forest.

Detailed analyses covered six research areas in the gminas which are traversed by the selected road sections, namely:

(a) 16 gminas crossed by road A1 along Pruszcz Gdański-Grudziądz section (operational since 2008) and road DK91 (referred to as A1 in the text, tables and figures);

(b) 15 gminas crossed by road A4 along Wrocław-Opole section (operational since 2003) and road DK94 (A4);

(c) 17 gminas crossed by road DK8 along Kudowa Zdrój-Wrocław section (DK8K);

(d) 6 gminas crossed by road DK8 along Augustów-Budzisko section (DK8A);

(e) 10 gminas crossed by road DK17 along Garwolin-Kurów section (DK17);

(f) 6 gminas crossed by road S8 along section Radzymin-Wyszków (the modernised section operational since 2009) (S8).

A digital map at a scale of 1:25000 showing the 2002 status was used to determine the forest fragmentation for each research area. The data were supplemented and upgraded using materials downloaded from Geoportal 2, which included an orthophotomap and structures from the Database of Topographic Object (BDOT, as at 2013). The materials were collected and processed in the ArcGis environment. Commonly used indicators were applied to measure fragmentation, (cf. Richling \& Solon 2011), presented in Table 1.

Data on traffic incidents which involved animals cover the years 2006-2012 and originate from the SEWIK database run by the National Police Headquarters. In this database all traffic incidents are characterised using many variables. Two characteristics may be suitable for selection of the number of incidents involving animals. The variable SZRD defines incident type. One incident category, coded as 09 , stands for "running over an animal". The second variable, SPIP, defines incident causes. Its category 08 stands for "objects, animals on the road". Analysis of SEWIK database shows that in some years there was $10-15 \%$ more incidents on the SPIP list than on the SZRD list. Considering the nature of both characteristics, further analyses take into account only incidents in the case of which it has been explicitly concluded that they resulted from "running over an animal". After selection of

1 The paper presents the findings from the research project under the grant agreement no. NN 306564940 financed with the resources from the National Science Center. 
a set, each incident was characterised using the following variables: location, road type, speed limit, time (date and time). These data have been entered to the GIS system and then presented on maps and analysed in statistical terms.

Table 1. Abbreviations and explanations of the indicators used to describe the forest fragmentation

\begin{tabular}{|c|c|c|c|}
\hline No & Indicator & Indicator identification & Formula \\
\hline 1 & $\mathrm{Sh}<10$ & $\begin{array}{l}\text { Share of forest patches below } 10 \text { ha surface area } \\
\text { in the total number of patches }\end{array}$ & \\
\hline 2 & $\mathrm{MNND}<10$ & $\begin{array}{l}\text { Mean nearest neighbour distance }(\mathrm{m}) \text { for forest } \\
\text { patches below } 10 \text { ha surface area }\end{array}$ & \\
\hline 3 & $\mathrm{Sh}>30$ & $\begin{array}{l}\text { Share of forest patches exceeding } 30 \text { ha surface } \\
\text { area in the total number of patches }\end{array}$ & \\
\hline 4 & MNND $>30$ & $\begin{array}{l}\text { Mean nearest neighbour distance }(\mathrm{m}) \text { for forest } \\
\text { patches exceeding } 30 \text { ha surface area }\end{array}$ & \\
\hline 5 & NumP & Total number of forest patches & \\
\hline 6 & MNND & $\begin{array}{l}\text { Mean nearest neighbour distance }(\mathrm{m}) \text { for all forest } \\
\text { patches }\end{array}$ & \\
\hline 7 & MPS & Average patch size (ha) & MPS $=\left(\sum a\right) / n$ \\
\hline 8 & PSCoV & Patch size coefficient of variance & $\begin{array}{l}\mathrm{PSCoV}=(\mathrm{SD} / \mathrm{MPS}) \cdot 100 \\
\mathrm{SD}=\left(\left(\sum(\mathrm{a}-\mathrm{MPS})^{2}\right) / \mathrm{n}\right)^{0.5}\end{array}$ \\
\hline 9 & MSI & Mean patch shape index & $\mathrm{SI}=\mathrm{p} /\left(2(\pi \cdot \mathrm{a})^{05}\right) ; \mathrm{MSI}=\left(\sum \mathrm{SI}\right) / \mathrm{n}$ \\
\hline 10 & AWMSI & Area-weighted mean patch shape index & AWMSI $=\left(\sum(\mathrm{SI} \cdot \mathrm{a})\right) / \sum \mathrm{a}$ \\
\hline 11 & MPFD & Mean patch fractal dimension & $\mathrm{PFD}=2 \ln \mathrm{p} / \ln \mathrm{g} ; \mathrm{MPFD}=\left(\sum \mathrm{PFD}\right) / \mathrm{n}$ \\
\hline 12 & AWMPFD & Area-weighted mean patch fractal dimension & $\mathrm{AWMPFD}=\left(\sum(\mathrm{PFD} \cdot \mathrm{a})\right) / \sum \mathrm{a}$ \\
\hline & \multicolumn{3}{|c|}{ Additional symbols: $\mathrm{a}$ - patch surface area, $\mathrm{p}$ - patch perimeter, $\mathrm{n}$ - number of patches. } \\
\hline
\end{tabular}

Source: indicators 1-4 - own proposal, indicators 5-12 according to McGarigal \& Marks (1995).

\section{Major effects of linear road projects on spatial structure and functioning of landscape}

According to the definition in the European Landscape Convention, "landscape" means an area, as perceived by people, whose character is the result of the action and interaction of natural and/ or human factors. Despite apparent simplicity the definition synthesises various aspects of reality that exist objectively and are subjectively interpreted. In particular, landscape understood as per the definition is primarily a spatial structure where important role is played by biotic and abiotic elements and processes, which, together with anthropogenic objects that piled up through centuries, create a common structural and functional system with well-demarcated cause and effect relations. Landscape thus understood, composed of three partially independent hierarchical spaces: abiotic - expressed by geodiversity, biotic - reflected in biodiversity, and social - conveyed by diversity introduced by humans, should be treated at the same time as (Richling \& Solon 2011):

- a set of physical structures, their aggregations, configurations and sub-systems (abiotic, biotic, anthropogenic);

- a system of interrelated processes (environmental, geomorphologic, hydrologic, aeolian, biogeochemical, economic, social and other processes) integrating physical structures; 
- a set of stimuli on various senses of the user (sight, hearing, smell), including in particular a set of views and panoramas of specific aesthetic values;

- a set of natural, social, economic, financial, spiritual, historical and other values (potentials), which are usually of relative significance;

- a system that provides actual and potential services to various groups of users.

It should be emphasised that the two former categories are objective, they exist regardless of the will, views and attitude of the recipient (user), while the three remaining categories are relative and depend on the perception capacity, needs, cultural context, economic conditions and preferences of the user.

Every anthropogenic impact, especially creating new spatial structures, affects the above-mentioned landscape aspects. Also roads and other transport routes cause numerous usually irreversible changes in the landscape structure and functioning. The major types of these impacts are presented in Table 2.

It should be noted that the intensity of individual forms of road influence and its territorial scope, as well as intensity of landscape transformation, depend on many factors of which the most important are: (a) road category, or its width, associated facilities, manner and level of technical isolation from the surroundings, etc.; (b) period of use (one the one hand, new roads exert intensive direct influence fast, and on the other hand, direct influence of roads in use for a long time is extinguished, while indirect influence is very wide); (c) relief and land cover structure in landscape cut by roads.

Table 2. Major types of road impact on landscape structure and functioning

\begin{tabular}{|c|c|c|}
\hline & A. Direct impact & $\begin{array}{c}\text { B. Indirect impact } \\
\text { (delayed in time and at large scale) }\end{array}$ \\
\hline \multirow{5}{*}{ 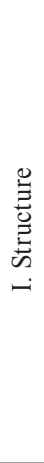 } & $\begin{array}{l}\text { I.A.1. New spatial element in landscape (linear with } \\
\text { local engineering structures: bridges, viaducts) }\end{array}$ & \multirow[t]{2}{*}{$\begin{array}{l}\text { I.B.1. Orientation of creation of other new anthropo- } \\
\text { genic structures (attraction areas) }\end{array}$} \\
\hline & $\begin{array}{l}\text { I.A.2. New habitats, frequently xerophytic and } \\
\text { non-forest }\end{array}$ & \\
\hline & $\begin{array}{l}\text { I.A.3. Reduction of surface area of traversed } \\
\text { habitats and ecosystems, including a reduction } \\
\text { of the surface area of ecosystem core }\end{array}$ & \multirow[t]{3}{*}{ I.B.2. Increased landscape synanthropisation } \\
\hline & $\begin{array}{l}\text { I.A.4. Changes in abiotic conditions (foreign } \\
\text { substrate and hydrological changes) and pollution } \\
\text { of the environment }\end{array}$ & \\
\hline & $\begin{array}{l}\text { I.A.5. Changes in landscape spatial structure } \\
\text { indicators (composition and configuration) }\end{array}$ & \\
\hline \multirow{4}{*}{ 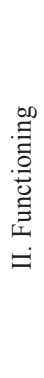 } & II.A.1. Crossing of wildlife corridors & $\begin{array}{l}\text { II.B.1. Changes in migration routes of many species } \\
\text { (disappearance of old and/or emergence of new } \\
\text { routes) }\end{array}$ \\
\hline & II.A.2. Emergence of and rise in the barrier effect & $\begin{array}{l}\text { II.B.2. Changes in home ranges and travel routes } \\
\text { of animals within landscape }\end{array}$ \\
\hline & \multirow[t]{2}{*}{ II.A.3. Decrease in functional cohesion of landscape } & $\begin{array}{l}\text { II.B.3. Changes in the dynamics of metapopulation } \\
\text { (including size, death rate (also caused by minor road } \\
\text { incidents), number of inhabited patches) }\end{array}$ \\
\hline & & $\begin{array}{l}\text { II.B.4. Higher openness of landscape to external } \\
\text { impact (including biological invasions) }\end{array}$ \\
\hline
\end{tabular}

Source: own study. 
Fragmentation of ecosystems generally results in a decrease in surface area of individual patches, which is consequence leads inter alia to:(a) visible reduction of so-called patch core area, or an area which is not subject to edge zone impact; (b) relative extension of patch border line, which facilitates entry of ecologically alien species from the surrounding areas; (c) greater vulnerability to negative external influence. All of this results in changes in the species composition manifested by a decrease in the number or extinction of rare species which require vast ranges, by spreading of common and eurytopic species. Adverse changes combined with fragmentation concern all types of ecosystems, but in Poland the processes that are important due to general environmental consequences include fragmentation in forest and peat-bog ecosystems and in marsh areas in general.

Fragmentation by cutting natural and half-natural ecosystems by traffic routes results in creating environmental barriers, or comprehensive impact (covering death rate, physical access restriction and scarring off) that prevents free and successful road crossing by certain animal groups. Environmental barriers connected with the effect of road infrastructure take the form of: (a) physical barriers; (b) psychophysical barriers (Kurek 2010a, 2010b). Physical barriers hinder animal movement due to artificial land modifications, introduction of protective fences, screens, nets and presence of anthropogenic structures (traffic control facilities and devices, traffic safety enhancement devices), etc. The psychophysical barrier consists in scaring off animals and causing a reduction in intensity of animals' presence in the vicinity of roads as a result of presence of traffic-driven impacts (noise, light and chemical emissions).

Based on numerous Polish and foreign studies, including the analyses and lists in the Environmental Impact Assessment of the Programme for the Construction of National Roads for 2011-2015 (Environmental... 2011) quoted above, three categories of impact on wildlife corridors for roads without protective fences or wildlife crossings have been distinguished:

1. Insignificant (low) barrier effect - traffic intensity between 500 and 2,500 vehicles per 24 hours; interruption of corridor functioning for the majority of small land animals (amphibians, invertebrates); very high/high death rate of small animals; in the case of low speed $(<70 \mathrm{~km} / \mathrm{h})$ it is possible to maintain functioning of wildlife corridors for large and medium mammals.

2. Strong (considerable) barrier effect - traffic intensity between 2,500 and 10,000 vehicles per 24 hours; total interruption of corridor functioning for small land animals; very high/high death rate of all groups of animals (including the ungulates); lower intensity of penetration of areas adjacent to the road by large forest mammals (scaring off animals); in the case of low speed $(<70 \mathrm{~km} / \mathrm{h})$ and in the case of large decreases in traffic intensity at night it is possible to maintain functioning of wildlife corridors for large and medium-sized mammals.

3. Very strong (considerable) barrier effect - traffic intensity in excess of 10,000 vehicles per 24 hours; total interruption of corridor functioning for all land animal species; high death rate of all groups of animals; lower intensity of penetration of areas adjacent to the road by large forest mammals (scaring off animals); in the case of large decreases in traffic intensity at night it is possible to maintain partial functioning of local migration routes of the ungulates.

All barrier effects caused by roads are difficult to observe and register as it would require especially planned long-term research. One element of this intricate set of interrelationships which is relatively easier to analyse is the animal death rate on roads. Studies on the subject are becoming increasingly popular in Poland, although we still have no overall picture of the issue. Basically, research to-date has focused on three thematic scopes to which diverse methodological approaches correspond. Data used most frequently are provided by Voivodeship Police Headquarters or by the National Police headquarters, and the analyses include diversification of the number of incidents 
involving animals depending on road category, season and time of the day in regional or national terms (e.g. Borowska 2010; Czerniak \& Tyburski 2011; Tyburski et al. 2012). Due to high labour intensity, road kills are counted on conventionally selected road sections much less frequently. Usually, it is done on foot or by capturing video from a slowly moving car (Tyburski \& Czerniak 2012). A completely different approach envisages the drivers' survey method. Surveys do not allow to determine the number of incidents involving animals nationwide or in the regions but they do help assess the proportion of the death rate of small animals and large ungulates and determine the so-called "invisible number" or the number of incidents not reported to the forest district office or to the police (Borowska 2008).

\section{General characteristics of selected fragments of transport corridors}

\section{Location of test areas in relation to protected sites}

In terms of location in relation to protected sites the test areas under analysis can be divided into three distinct groups (Tab. 3). The first group covers an A4 section. It is characterised by the relatively lowest forest ratio (the average for the entire area under analysis and in the individual gminas). In the mentioned area road A4 does not cross any wildlife corridors of regional or national rank, but it runs through two Natura 2000 sites at a distance of ca $1 \mathrm{~km}$.

The second group covers DK8A area. It is characterised by the highest average forest ratio (about $35 \%$ ) and diversified forest ratio in individual gminas (between $13 \%$ and over $60 \%$ ). In this area road DK8 crosses two Natura 2000 Natura 2000 sites at a distance of over $20 \mathrm{~km}$, of which $12 \mathrm{~km}$ are wildlife corridor crossings.

The other areas form the third intermediate group. The average forest ratio ranges between $20 \%$ and $26 \%$, with very uneven spatial distribution of forest areas. The communication routes under analysis cross 1-2 Natura 2000 sites and the length of road sections crossing sanctuaries is between about $4 \mathrm{~km}$ and about $8 \mathrm{~km}$ (outside the built-up areas), while the length of main road stretches crossing wildlife corridors ranges between about $14 \mathrm{~km}$ and over $25 \mathrm{~km}$.

None of the test areas under analysis has a direct conflict between main communication routes and national parks or nature reserves. Links with landscape parks (i.e. cutting through or proximity) are present only in the case of DK91 (A1 area), and each route runs through at least one protected landscape site. 
Table 3. Location of communication routes in test areas in relation to the protected sites and wildlife corridors

\begin{tabular}{|c|c|c|c|c|c|}
\hline $\begin{array}{l}\text { Route in } \\
\text { test area }\end{array}$ & $\begin{array}{l}\text { Average } \\
\text { forest } \\
\text { ratio } \\
(\%)^{a}\end{array}$ & $\begin{array}{l}\text { Forest ratio } \\
\text { in gminas } \\
(\%) \\
\min / / \max ^{b}\end{array}$ & $\begin{array}{l}\text { Natura } 2000 \\
\text { sites (crossed } \\
\text { or closely } \\
\text { located)c }\end{array}$ & $\begin{array}{l}\text { Protected sites (crossed or closely } \\
\text { located) }\end{array}$ & $\begin{array}{l}\text { Wildlife } \\
\text { corridors } \\
\text { (crossed) }^{\mathrm{d}}\end{array}$ \\
\hline A1 & 21.2 & $1 / / 56$ & $\begin{array}{l}\text { PLH040022, } \\
\text { PLB220009 }\end{array}$ & $\begin{array}{l}\text { Protected Landscape Site of Radunia } \\
\text { Valley, Eastern Protected Landscape Site } \\
\text { of Tuchola Forest, Complex of Vistula } \\
\text { River Landscape Parks }\end{array}$ & $\begin{array}{l}\text { GKPn-10A, } \\
\text { GKPn-13 }\end{array}$ \\
\hline A4 & 13.3 & $1 / / 29$ & $\begin{array}{l}\text { PLH160014, } \\
\text { PLH160005 }\end{array}$ & $\begin{array}{l}\text { Protected Landscape Site Niemodlin } \\
\text { Forest }\end{array}$ & N/A \\
\hline DK8K & 25.7 & $1 / / 79$ & $\begin{array}{l}\text { PLH020062, } \\
\text { PLH020004, } \\
\text { PLH020060, } \\
\text { PLB020006 }\end{array}$ & $\begin{array}{l}\text { Protected Landscape Site Bardzkie and } \\
\text { Sowie Mountains }\end{array}$ & $\mathrm{KZ}-5, \mathrm{KZ}-5 \mathrm{~A}$ \\
\hline DK8A & 34.9 & $13 / / 61$ & $\begin{array}{l}\text { PLH200005, } \\
\text { PLB200002 }\end{array}$ & $\begin{array}{l}\text { Protected Landscape Site Biebrza } \\
\text { River Valley, Protected Landscape Site } \\
\text { Augustów Forest and lakes, Protected } \\
\text { Landscape Site Northern Suwałki Region } \\
\text { Lake District }\end{array}$ & $\begin{array}{l}\text { GKPn-4A, } \\
\text { GKPn-4, } \\
\text { GKPn-4C }\end{array}$ \\
\hline DK17 & 20.4 & $2 / / 35$ & PLH060051 & $\begin{array}{l}\text { Protected Landscape Site Wieprz River } \\
\text { Valley }\end{array}$ & $\begin{array}{l}\text { GKPdC-4C, } \\
\text { KPdC-1A }\end{array}$ \\
\hline S8 & 25.4 & $22 / / 32$ & $\begin{array}{l}\text { PLH140011, } \\
\text { PLB140001 }\end{array}$ & Warsaw Protected Landscape Site & GKPnC-2 \\
\hline
\end{tabular}

Data sources: a - calculation based on the map; b - Local Data Bank of the Central Statistical Office (http://stat.gov.pl/bdlen/); c - Geoserwis by the General Directorate for Environmental Protection (geoserwis.gdos.gov.pl); d - Jędrzejewski et al. 2005, 2006.

\section{Forest land fragmentation in test areas}

Analysis of topographic maps at a scale of 1:50000 and 1:100000 from the years 1950-2000 shows that in the given period there were only slight changes in the distribution of forests in test areas. In the selected gminas, as throughout Poland, the surface area of forests also increased (yet only slightly) whereas changes in the values of spatial landscape structure indicators were low and proved constancy of forest distribution patterns.

The current status of forest fragmentation is presented in Table 4. In all test areas the total number of forest patches (NumP) is between 163 and 237, and always small patches (below 10 ha) prevail: they constitute between $53 \%$ and $70 \%$ of the total number of patches. Patches with surface area in excess of 30 ha are much less numerous (between $9 \%$ and $21 \%$ of the total number of patches). There is an interesting regularity: average distance between small patches is distinctly higher than between large patches (except for DK8A area). Such diversity shows that there are two separate patterns of forest area distribution at the same time in all areas. They are: (a) small patches located far from each other in generally deforested landscape; (b) large patches near each other that constitute one relatively dense, although fragmented, forest complex. 
Table 4. Indicators of forest land fragmentation in test areas. Explanations of variables - cf. Table 2

\begin{tabular}{|l|c|c|c|c|c|c|}
\hline \multicolumn{1}{|c|}{ Indicator } & A1 & A4 & DK8A & DK17 & DK8K & S8 \\
\hline Sh $<10$ & 59.5 & 70.2 & 59.5 & 56.1 & 53.2 & 64.4 \\
\hline MNND $<10$ & 1,449 & 762 & 431 & 557 & 1,068 & 365 \\
\hline Sh>30 & 13.9 & 9.6 & 14.1 & 21.3 & 18.6 & 10.6 \\
\hline MNND $>30$ & 336 & 132 & 557 & 256 & 504 & 250 \\
\hline NumP & 237 & 208 & 163 & 230 & 188 & 180 \\
\hline MNND & 1,011 & 707 & 467 & 494 & 871 & 372 \\
\hline MPS & 98.06 & 57.62 & 167.40 & 73.80 & 97.50 & 52.90 \\
\hline PSCoV & 475.04 & 352.89 & 423.16 & 30.07 & 72.90 & 34.55 \\
\hline MSI & 1.59 & 1.62 & 1.75 & 1.75 & 1.87 & 2.23 \\
\hline AWMSI & 3.33 & 2.54 & 3.05 & 1.78 & 1.90 & 2.32 \\
\hline MPFD & 1.289 & 1.306 & 1.305 & 1.196 & 1.207 & 1.221 \\
\hline AWMPFD & 1.295 & 1.282 & 1.277 & 1.196 & 1.203 & 1.223 \\
\hline
\end{tabular}

Source: own study.

Further analysis of the indicators in Table 4 shows that the test areas under analysis can form two groups. The first one which covers the areas A1, A4 and DK8A is characterised by a high internal diversification of the size of forest patches on surfaces and high variability of patch shapes with have much more irregular shapes for large forest patches compared to small patches. Areas which fall with the second group (DK17, DK8K and S8) display low values of the patch surface area variance indicator and very slight difference in the shape of large and small patches.

Regardless of the general spatial structure of forests, the environmental functions of roads (including the barrier function) are affected in particular by the length and number of road sections crossing the forests (Tab. 5). In this respect, the most potential conflicts may arise in DK8A area, while $\mathrm{S} 8$ and DK8K areas are the least problematic.

Table 5. Route through the forest in test areas

\begin{tabular}{|l|c|c|c|}
\hline \multirow{2}{*}{ Traverse } & Road No. & Road length in the forest $\mathbf{( k m )}$ & Number of crossings \\
\hline \multirow{2}{*}{ A1 } & A1 & 15.8 & 24 \\
\cline { 2 - 4 } & DK91 & 7.8 & 16 \\
\cline { 2 - 4 } A4 & A4 & 14.2 & 6 \\
\hline \multirow{2}{*}{ DK8K } & DK94 & 0 & 7 \\
\hline DK8A & DK8 & 7.7 & 14 \\
\hline \multirow{2}{*}{ DK17 } & DK8 & 21.9 & 11 \\
\hline \multirow{3}{*}{ S8 } & DK17 & 11.2 & 5 \\
\cline { 2 - 4 } & old section & 2.9 & 4 \\
\cline { 2 - 4 } & new section & 2.2 & 4 \\
\hline
\end{tabular}

Source: own study.

Taking into account merely natural considerations, such as current total forest ratio, number of patches and their location with respect to each other, the degree of complexity of forest land borders, 
and the number and length of sections of main roads under analysis within forest complexes, it can be assumed that the areas under analysis (considered as a whole, without separate consideration of the main roads) should not differ much in terms of likelihood of "running over an animal" incidents.

\section{Traffic incidents involving animals: analysis of selected road sections}

\section{National trends in changes in the number of incidents involving animals}

Between 2006 and 2012 the number of traffic incidents registered in SEWIK database decreased from over 450,000 to less than 380,000 . The number of accidents decreased at a comparable rate: from about 47,000 to ca. 37,000. The role of incidents (accidents) involving animals increased considerably in that period of time. In the case of all incidents in total the share of "running over an animal" incidents increased from about $3 \%$ to over $5 \%$, while among accidents it increased from close to 4 per mille to over 8.5 per mille (Fig. 1).

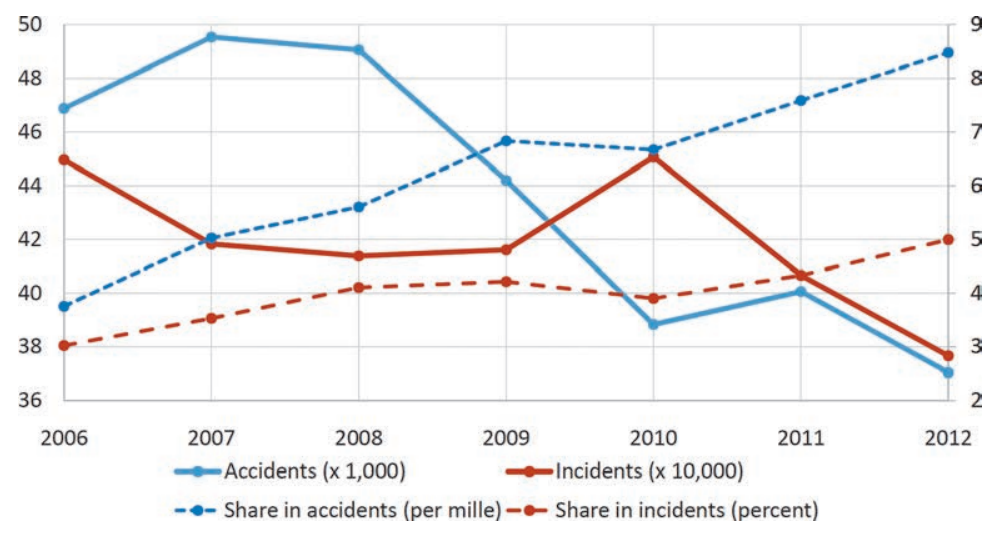

Figure 1. General trends in the number of traffic incidents between 2006 and 2012. Explanations: Horizontal axis - years; left vertical axis - absolute number of traffic incidents (in tens of thousands) and accidents (in thousands); right vertical axis - the share of incidents involving animals (percent) and the share of accidents involving animals (per mille)

Source: own study.

Long-term increase in the number of incidents involving animals displayed seasonal variations (Fig. 2). The highest numbers of incidents involving animals occur during the spring peak (April, May) and autumn peak (October, November, December). These were also the seasons with the highest percentage share: it increased from about four in 2006 to nearly six in 2009. In the same years the number of traffic incidents involving animals was the lowest in January and February and increase in their share was visible slower: from about $2 \%$ in 2006 to over 3\% in 2009. The same trend of fast increase in maximum shares of incidents involving animals in the total number of incidents compared to minimum shares also occurred in subsequent years. 


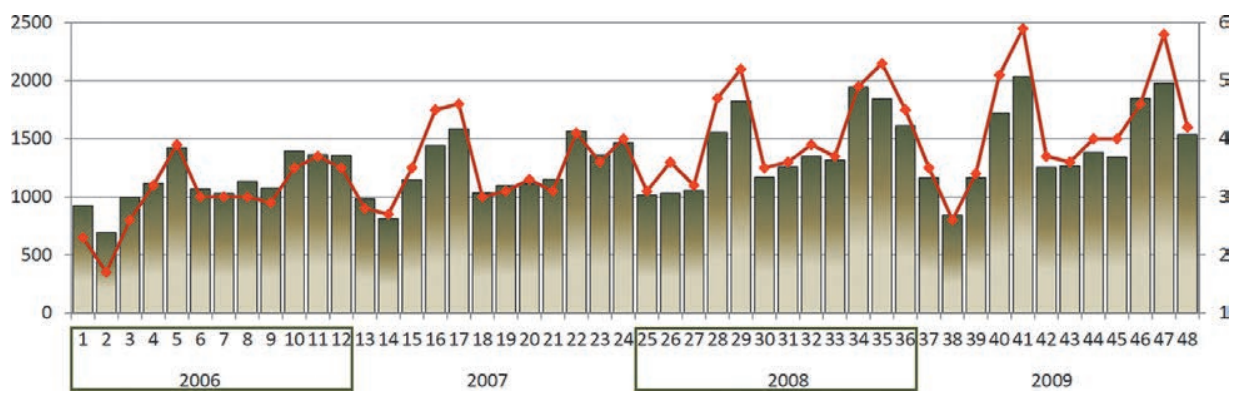

Figure 2. Seasonal changes in the number of "running over an animal" incidents between 2006 and 2009 nationwide. Left vertical axis - number of incidents per month; right vertical axis - share of "running over an animal" incidents in the total number of traffic incidents (percent)

Source: own study.

\section{Temporal fluctuations of the number of incidents involving animals in test areas}

The test areas under analysis differ in terms of the pace of changes in the number of "running over an animal" incidents between 2006 and 2012 (Tab. 6). In the areas A4 and DK8A the average annual number of incidents (in general and at night outside the built-up areas) has not changed significantly. The strongest growing tendency occurred in DK17 and S8 areas, whereas in the latter the changes in the number of incidents are attributable to a large extent to road modernisation completion. It is interesting that this growth did not occur in the day and at night to the same extent. Analysis of differences between the values of parameter " $b$ " in trend line pairs for individual test areas shows that in areas A1, DK17 and S8 the number of incidents involving animals during the day increased considerably stronger than the number of incidents at night outside the built-up areas. In other areas these differences were insignificant.

Table 6. Parameters of linear function of trend $y=a+b x$ for: (A) all traffic incidents "running over an animal" between 2006 and 2012, and (B) for the number of incidents at night (between 6 pm and 6 am) outside the built-up areas (speed limit exceeding $70 \mathrm{~km} / \mathrm{h}$ )

\begin{tabular}{|l|c|c|c|c|}
\hline \multicolumn{1}{|c|}{ Section } & a & b & Standard error & Coefficient of correlation \\
\hline A1 (A) & 6.6044 & 0.0306 & 4.5465 & 0.1629 \\
\hline A1 (B) & 3.2235 & 0.0180 & 3.0822 & 0.1418 \\
\hline A4 (A) & 8.4974 & -0.0033 & 4.0103 & 0.0202 \\
\hline A4 (B) & 5.8049 & 0.0015 & 3.2412 & 0.0114 \\
\hline DK8K (A) & 6.4831 & 0.0267 & 3.5485 & 0.1818 \\
\hline DK8K (B) & 2.5376 & 0.0240 & 2.3010 & 0.2484 \\
\hline DK8A (A) & 3.9986 & 0.0070 & 2.4572 & 0.0701 \\
\hline DK8A (B) & 2.3098 & -0.0048 & 1.5731 & 0.0742 \\
\hline DK17 (A) & 4.8491 & 0.0486 & 3.3813 & 0.3329 \\
\hline DK17 (B) & 2.2613 & 0.0247 & 2.2790 & 0.2567 \\
\hline S8 (A) & 0.9925 & 0.0584 & 2.3641 & 0.5187 \\
\hline S8 (B) & -0.1480 & 0.0363 & 1.6121 & 0.4832 \\
\hline
\end{tabular}

Source: own study. 
As mentioned above, the number of incidents varies seasonally. There are two periods with a higher number of incidents (spring and autumn) and two periods with a very low number of incidents: the winter minimum and, less pronounced, the summer minimum (Fig. 3 and Fig. 4). The detailed distribution of minimums and maximums differs slightly in individual test areas.

In the area A1 the average multiannual minimums for 2006-2012 fall in January and September, although in particular years they may fall in periods December-March and August-September. On average, the maximum numbers of incidents involving animals occur in May and October, and much less frequently in April or November.

In the area A4 the average multiannual minimums occur in January (possibly also in the period of December-March) and in August (with high year-to-year variability covering the period of June-October). The maximums occur in May (less often in April) and November.

In the area DK8K the multiannual minimum occurs in February (possibly also in January and March) and in July (less often in August or September). The maximum values occur in May (although in particular years they may occur between April and June) and November (less often in October or December).

In the area DK8A the multiannual minimum occurs in February (possibly also in January and March) and in August. In the long term, the maximum of incidents occurs in May (although in individual years it may occur between March and June) and in October (less often in September).

In the area DK17 the multiannual minimum occurs in February (possibly also in January and March) and in June (possibly also in the period July-September). Maximum values occur in May (less frequently in April) and in October (they are diversified between August and November).

In the S8 area the average minimum occurs in January (although in some years it occurs between November and February) and in July (with diversification between June and September). Maximum values occur in May (less frequently in April) and in October (they are diversified between August and October). It should be emphasised that in the $\mathrm{S} 8$ area the distribution of minimums and maximums is the most variable year-to-year compared to other areas.

There is no visible geographic relationship as far as the occurrence of maximums and minimums of the number of incidents involving animals is concerned in the particular test areas that could be linked with general climatic diversification of Poland. It seems, with general relationships connected with the seasons, specific changes in activity of animals (which is the main condition of changes in the number of incidents) rather depend on weather on a local and a regional scale. The above seasonal changes concern all incidents involving animals in total. In the case of incidents involving animals that take place at night (between $6 \mathrm{pm}$ and $6 \mathrm{am}$ ) outside the built-up areas the seasonal variation is basically the same, although less pronounced, being rather a result of a lower number of incidents in general than the dissimilarity of annual rhythms.

The above seasonal variability in test areas can be described in formal terms using a model of overlapping sinusoids (Fig. 3, Fig. 4, parameters in Tab. 7). 

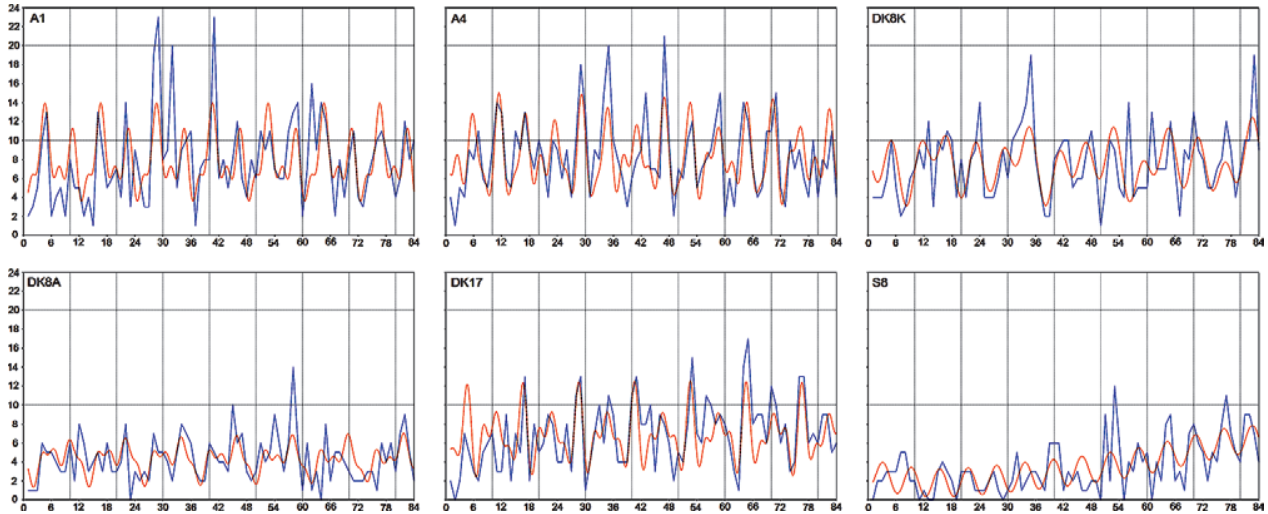

Figure 3. Long-term and seasonal variability of the number of all "running over an animal" incidents between 2006 and 2012. Blue line - actual number of incidents; red line - sinusoid model. Vertical axis - number of incidents; horizontal axis - successive months $(1=$ January 2006; 84 = December 2012).

Source: own study.
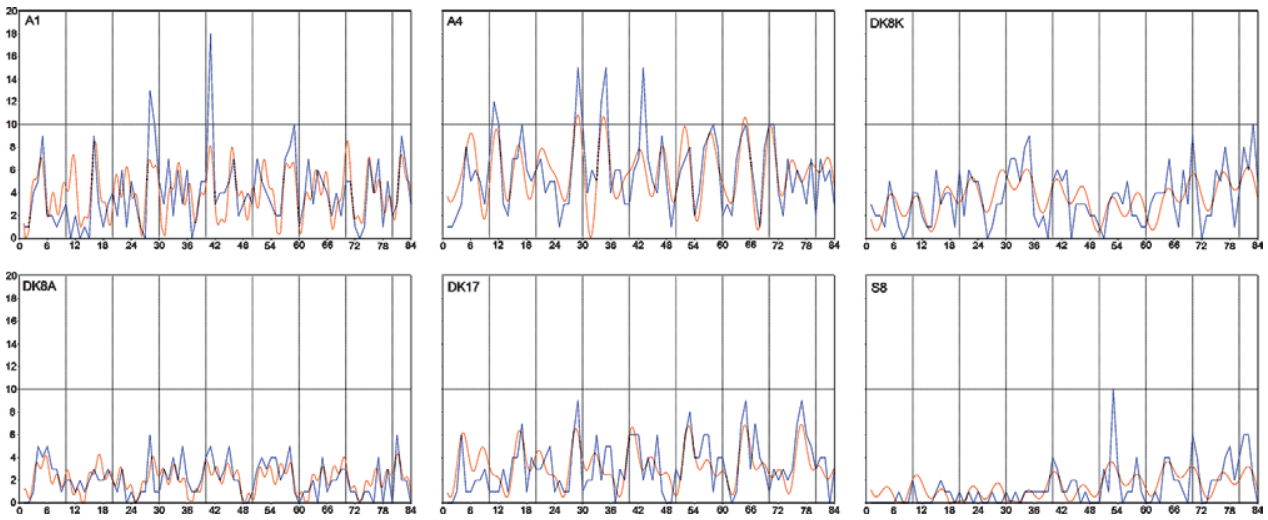

Figure 4. Long-term and seasonal variability of the number of "running over an animal" incidents at night (between $6 \mathrm{pm}$ and $6 \mathrm{am}$ ) outside the built-up areas (speed limit exceeding $70 \mathrm{~km} / \mathrm{h}$ ) between 2006 and 2012. Blue line - actual number of incidents; red line - sinusoid model. Vertical axis - number of incidents; horizontal axis - successive months $(1=$ January 2006; $84=$ December 2012)

Source: own study.

For all test areas under analysis, a model of compounding three sinusoids was applied. In each case one sinusoid had a period (T) of about six months, which roughly corresponds to the number of months between successive maximums and minimums. Additionally, in all cases (apart from DK8K and S8) the next sinusoid has a period of about three months, and for the final one (except for A4) the period is longer than one year. In accordance with the above-mentioned variability of incidents in individual research areas, the models for areas A1 and A4 showed the highest amplitudes whereas the areas S8 and DK8A had the lowest amplitudes. For all test areas (except for S8) the value of determination coefficient $\mathrm{r} 2$ is higher for the number of incidents at night (between $6 \mathrm{pm}$ and $6 \mathrm{am}$ ) outside the built-up areas than for all events in total. With these relationships in mind and taking into account visual analysis of the graphic presentation in figures 3 and 4 and analysis of the values of parameters $\mathrm{p}$ and $\mathrm{T}$ of sinusoids, it may be concluded that, in principle, there are no significant 
discrepancies between seasonal variability of all incidents involving animals and the number of incidents at night in the built-up areas, although for the majority of test areas the models concerning incidents at night explain more.

Table 7. Parameters of sinusoids in the form of $[y=a \cdot \cos (2 \cdot \pi \cdot(x-x 0) / T-p)+c]$ describing seasonal variability of the number of incidents involving animals between 2006 and 2012 for: (A) all incidents, and (B) for the number of incidents at night (between $6 \mathrm{pm}$ and $6 \mathrm{am}$ ) outside the built-up areas (speed limit exceeding $70 \mathrm{~km} / \mathrm{h})$

\begin{tabular}{|l|c|c|c|c|c|c|c|c|c|c|c|}
\hline \multirow{2}{*}{ Section } & \multicolumn{3}{|c|}{ Sinusoid 1 } & \multicolumn{3}{c|}{ Sinusoid 2 } & \multicolumn{3}{c|}{ Sinusoid 3 } & \multirow{2}{*}{ c } & \multirow{2}{*}{ r2 } \\
\cline { 2 - 11 } & $\mathbf{a}$ & $\mathbf{p}$ & $\mathbf{T}$ & $\mathbf{a}$ & $\mathbf{p}$ & $\mathbf{T}$ & $\mathbf{a}$ & $\mathbf{p}$ & $\mathbf{T}$ & & \\
\hline A1 (A) & 3.04 & -2.69 & 6 & 1.76 & 1.39 & 3 & 1.47 & 2.31 & 12 & 7.905 & 0.3493 \\
\hline A1 (B) & 2.19 & -2.41 & 5.947 & 1.2 & -1.67 & 2.258 & 1.3 & -2.35 & 4.171 & 4 & 0.412 \\
\hline A4 (A) & 3.26 & -1.43 & 5.878 & 1.65 & -3.02 & 2.958 & 1.75 & 2 & 4.495 & 8.369 & 0.5066 \\
\hline A4 (B) & 2.51 & -1.94 & 5.913 & 1.7 & 2.08 & 4.495 & 1.6 & -1.89 & 7.324 & 5.909 & 0.5188 \\
\hline DK8K (A) & 2.27 & -1.88 & 5.965 & 1.37 & 2.16 & 9.714 & 1.31 & -1.07 & 16.96 & 7.587 & 0.358 \\
\hline DK8K (B) & 1.29 & -1.92 & 5.93 & 0.829 & -2.66 & 12 & 1.19 & -2.16 & 46.66 & 3.578 & 0.3672 \\
\hline DK8A (A) & 1.23 & -2.15 & 5.93 & 0.668 & -0.525 & 3 & 1.13 & -2.48 & 12.02 & 4.304 & 0.28012 \\
\hline DK8A (B) & 0.821 & -2.42 & 5.913 & 0.688 & 0.559 & 2.284 & 1.08 & 2.52 & 12.31 & 2.086 & 0.4793 \\
\hline DK17 (A) & 2.39 & -2.79 & 6.036 & 1.57 & 1.75 & 2.984 & 1.66 & -0.953 & 4.014 & 6.923 & 0.4301 \\
\hline DK17 (B) & 1.28 & 3.07 & 6.09 & 1.02 & -1.18 & 4.022 & 1.54 & 2.88 & 11.88 & 3.322 & 0.46537 \\
\hline S8 (A) & 1.48 & 2.24 & 6.109 & 16 & 2.17 & 79.73 & 17.5 & -1.09 & 83 & 3.726 & 0.45711 \\
\hline S8 (B) & 0.931 & -2.43 & 5.965 & 0.848 & -1.12 & 13.64 & 0.936 & -1.41 & 83 & 1.39 & 0.3643 \\
\hline
\end{tabular}

Source: own study.

Compared to the above seasonal variability of the number of "running over an animal" incidents at night outside the built-up areas, other specific categories in the majority of test areas do not show such a well-defined variability throughout a year (Fig. 5).

In the area $\mathrm{A} 1$ the number of incidents outside the built-up areas during the day attains its maximums in the same months as for the incidents occurring during the night, while variability in other months is low. The number of incidents at night in the built-up areas has also a similar pattern. However, the pattern of incidents occurring during the day within the built-up areas different: between June and October the number of incidents is low, and in the other months it is visibly higher.

In the area A4 the number of incidents during the day outside the built-up areas is similar throughout the year with one visible maximum in November. A different pattern applied to rare incidents within the built-up areas (without division into day and night): they occur more frequently in the first half of the year, and in the second half they are very rare.

In the area DK8K the variability of the number of incidents within the built-up areas (both during the day and at night) is similar to that at night in the built-up areas, but the periods of minimums and maximums are less pronounced and frequently shifted in time. The number of incidents during the day outside the built-up areas has a different variability pattern: higher values occur between November and January and lower variability occurs in the remaining months.

In the area DK8K the number of incidents during the day outside the built-up areas has higher values between November and January and lower, slightly variable values in the other months. The number of incidents within the built-up areas shows low variability throughout the year, with a barely visible maximum in October. 
In the area DK17 none of the categories shows a well-formed annual rhythm of minimums and maximums. In principle, the number of incidents is similar throughout the year with one period of visibly higher values. In the case of incidents during the day outside the built-up areas, this period spreads between October and January, while in the case of incidents during the day within built-up areas it is between August and November and for incidents at night it is the month of May.

The least visible seasonal regularities occur in the area S8. As to incidents during the day outside the built-up areas, higher values are observed in December with an equal number of incidents in the remaining months. For incidents in the built-up areas the fluctuating changes prevail, although for incidents at night a minimum in February is visible.
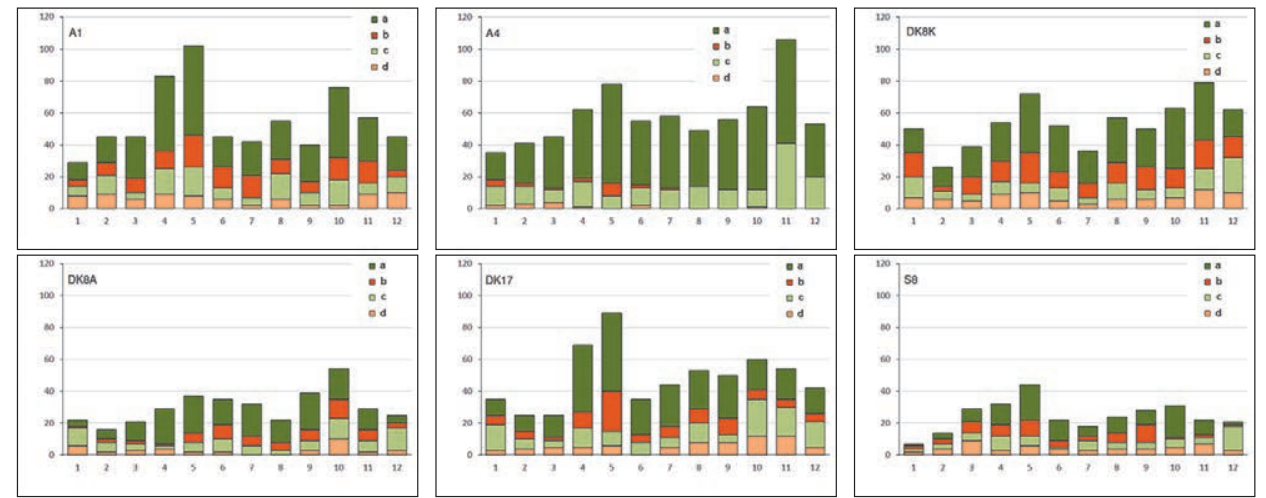

Figure 5. Seasonal variability of various categories of "running over an animal" incidents. Vertical axis - number of incidents; horizontal axis - successive months; a - night incidents outside built-up area; b - night incidents within built-up area; c - day incidents outside built-up area; $\mathrm{d}$ - day incidents within built-up area

Source: own study.

Generalizing from the above observations, it can be concluded that: (a) in all the test areas the variability of the number of incidents within the built-up areas considerably differs from that outside the built-up areas and may prove that these incidents are highly independent, concern different animals and have different causes; (b) outside the built-up areas incidents during the day have an autumn maximum delayed as compared to incidents at night and are spread over time, with simultaneous weaker spring maximum and periods of seasonal minimums.

\section{Spatial variability of the number of incidents involving animals in test areas}

\section{Distribution of incidents by road categories}

The analysis of the spatial distribution of incidents involving animals should take into account that in the three test areas (A1, A4 and S8) there are roads which constitute physical (mechanical) barriers because they are protected by nets, high barriers and acoustic screens. Presence of these technical structures have greater impact on the number of incidents involving animals than natural conditions and traffic intensity. In the remaining areas such barriers do not exists, and the number of incidents involving animals results mainly from psychophysical barriers and the spatial structure of landscape. 


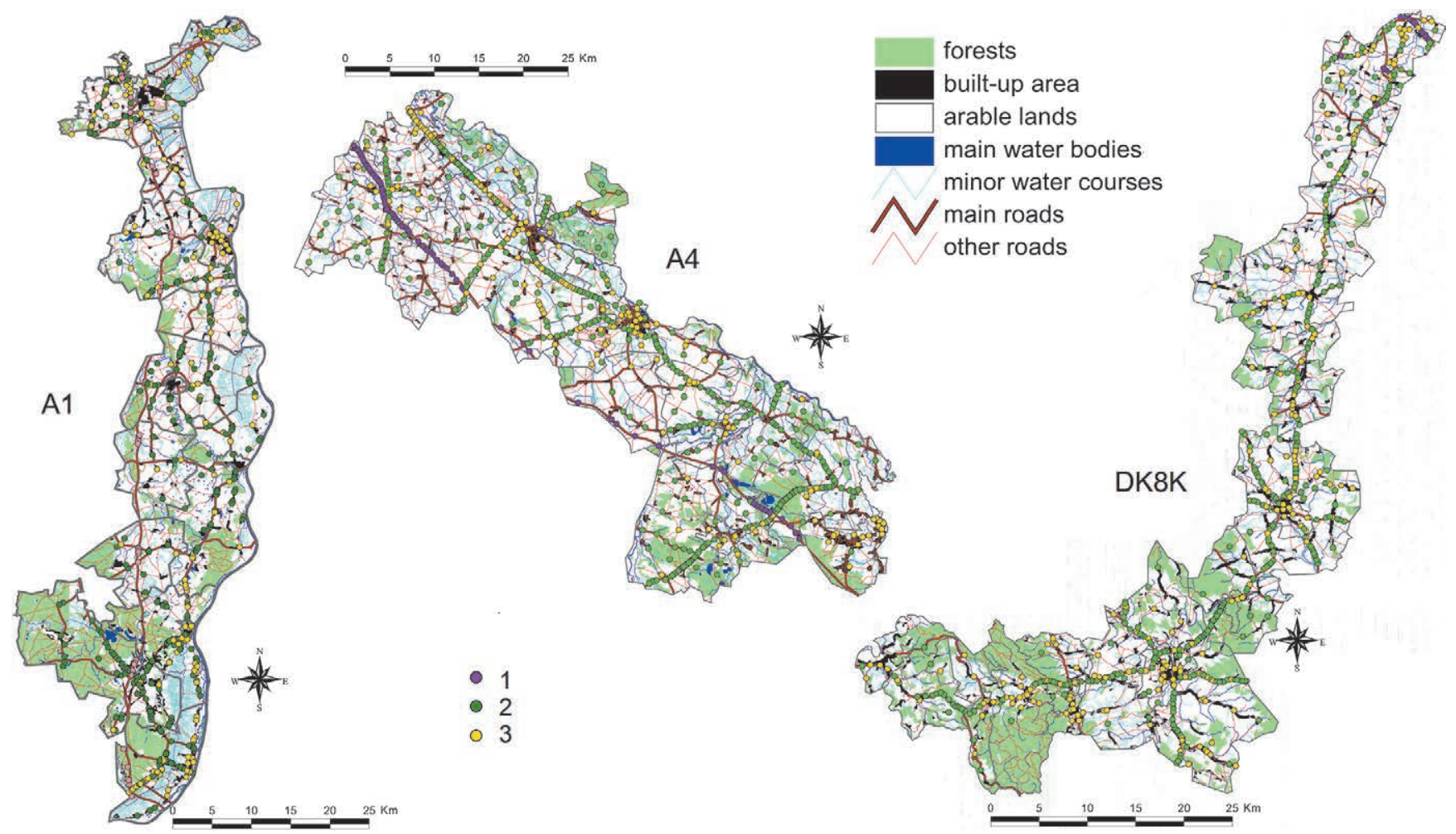

Figure 6a. Location of incidents by road category and presence of a built-up area. 1 - incidents on motorways and expressways, 2 - incidents on other roads outside built-up areas, 3 - incidents on other roads within built-up areas

Source: own study. 


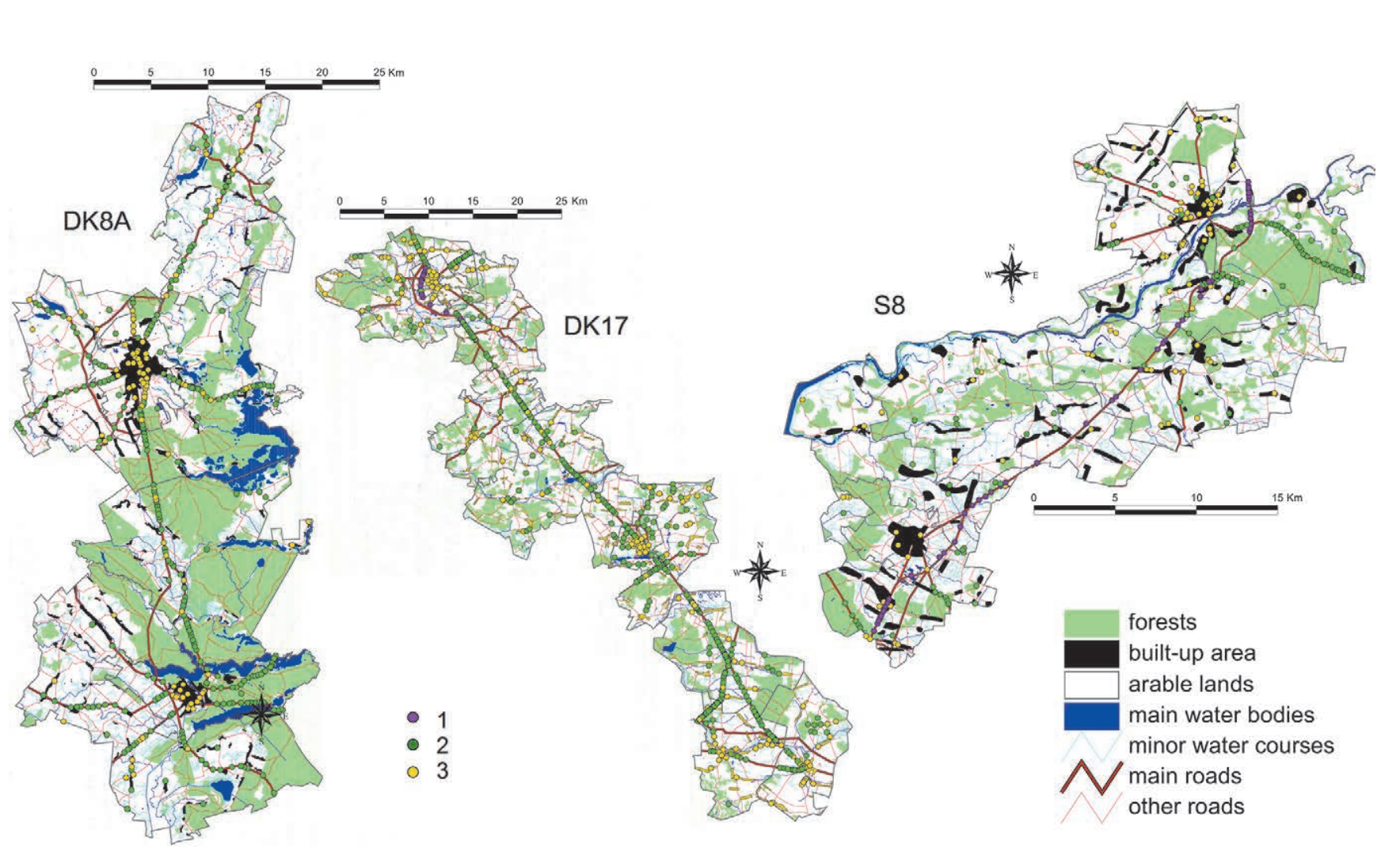

Figure 6b. Location of incidents by road category and presence of a built-up area. 1 - incidents on motorways and expressways, 2 - incidents on other roads outside built-up areas, 3 - incidents on other roads within built-up areas Source: own study. 
The areas A1 and A4 are relatively similar in terms of distribution of places where incidents involving animals occur (Fig. 6). Along the main body of motorways the incidents are relatively rare, but their number increases in the vicinity of intersections and interchanges. On the remaining roads, places where incidents involving animals occur are distributed relatively evenly and they are the most numerous on roads parallel with motorways which are equally intensively used (roads DK91 and DK94, respectively). It should be noted that the incidents involving animals are occasional on roads with low traffic intensity (local roads).

A different distribution pattern of incidents involving animals is characteristic of area S8. First of all, the central section of road S8 (commissioned in 2009 after modernisation) is characterised by exceptionally low number of incidents. They are concentrated in its southern part, in Radzymin gmina, and in the northern part, in Wyszków gmina. It should be noted that a great many incidents occur on the new Wyszków ring road, north of Lucynów interchange. The area is penetrated by animals intensively, as proven by high number and density of incidents on road No 62, parallel with Bug River valley.

Three other areas (DK8K, DK8A and DK17) display different patterns of distribution of incidents involving animals as they are distributed relatively evenly on main roads, on the majority of intersecting roads and within the built-up areas. Thus it seems that entire landscape in the areas is equally permeable for the majority of animals, regardless of the wildlife corridors of regional and national rank.

\section{Distribution of incidents by time of the day}

Analysis of Fig. 7 shows that the majority of incidents involving animals take place at night (i.e. between $6 \mathrm{pm}$ and $6 \mathrm{am}$ ). These incidents occur mainly outside the built-up areas, while, generally speaking, the majority of incidents during the day occur within built-up areas. This relationship concerns not only areas A4 and DK8A (where incidents during the day are relatively numerous on various roads), but also certain roads in areas DK8K and S8 where the number of incidents involving animals during the day and at night is similar. 


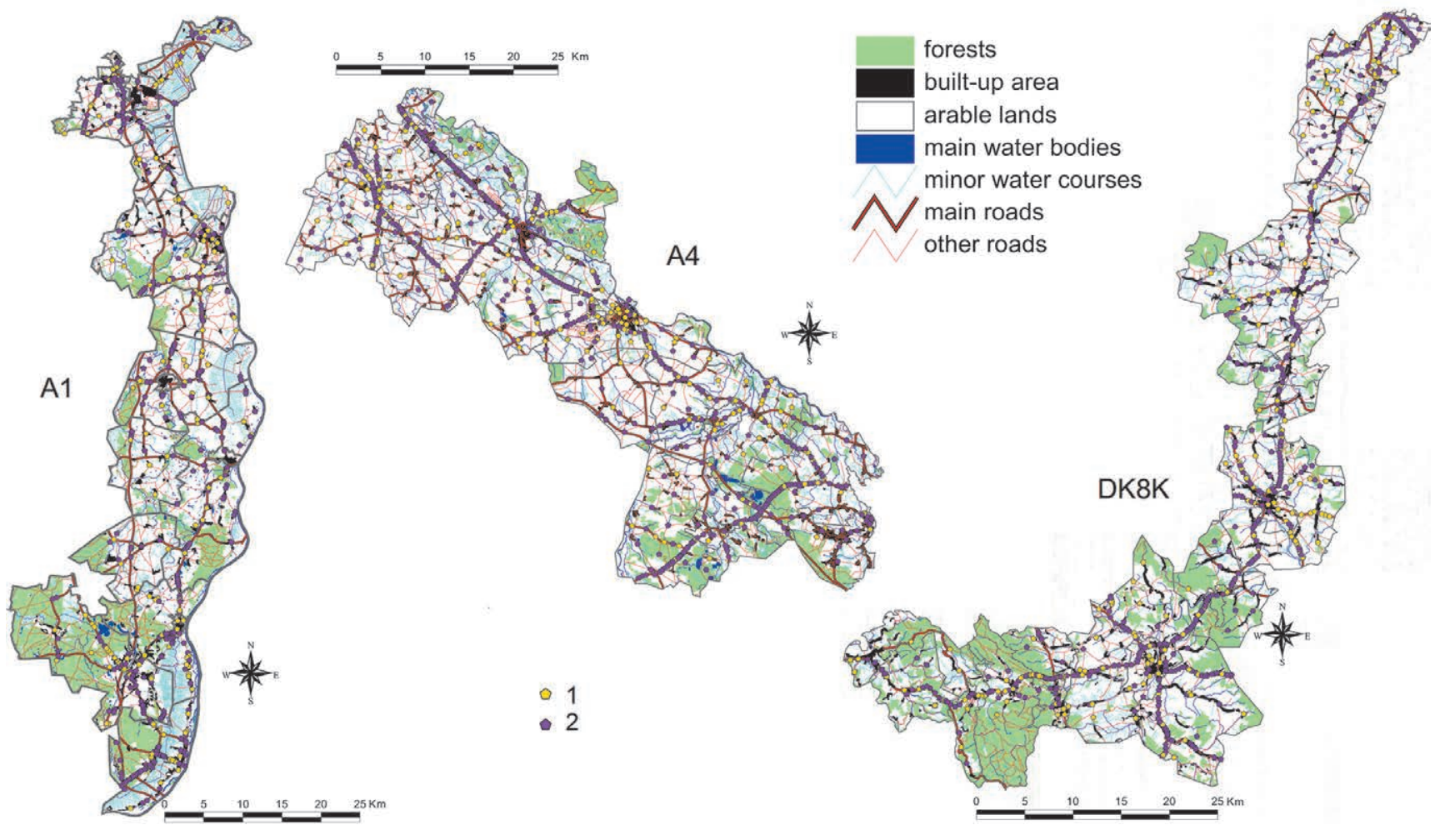

Figure 7a. Incident location by time of the day. 1 - daytime incidents 2 -night-time incidents Source: own study. 


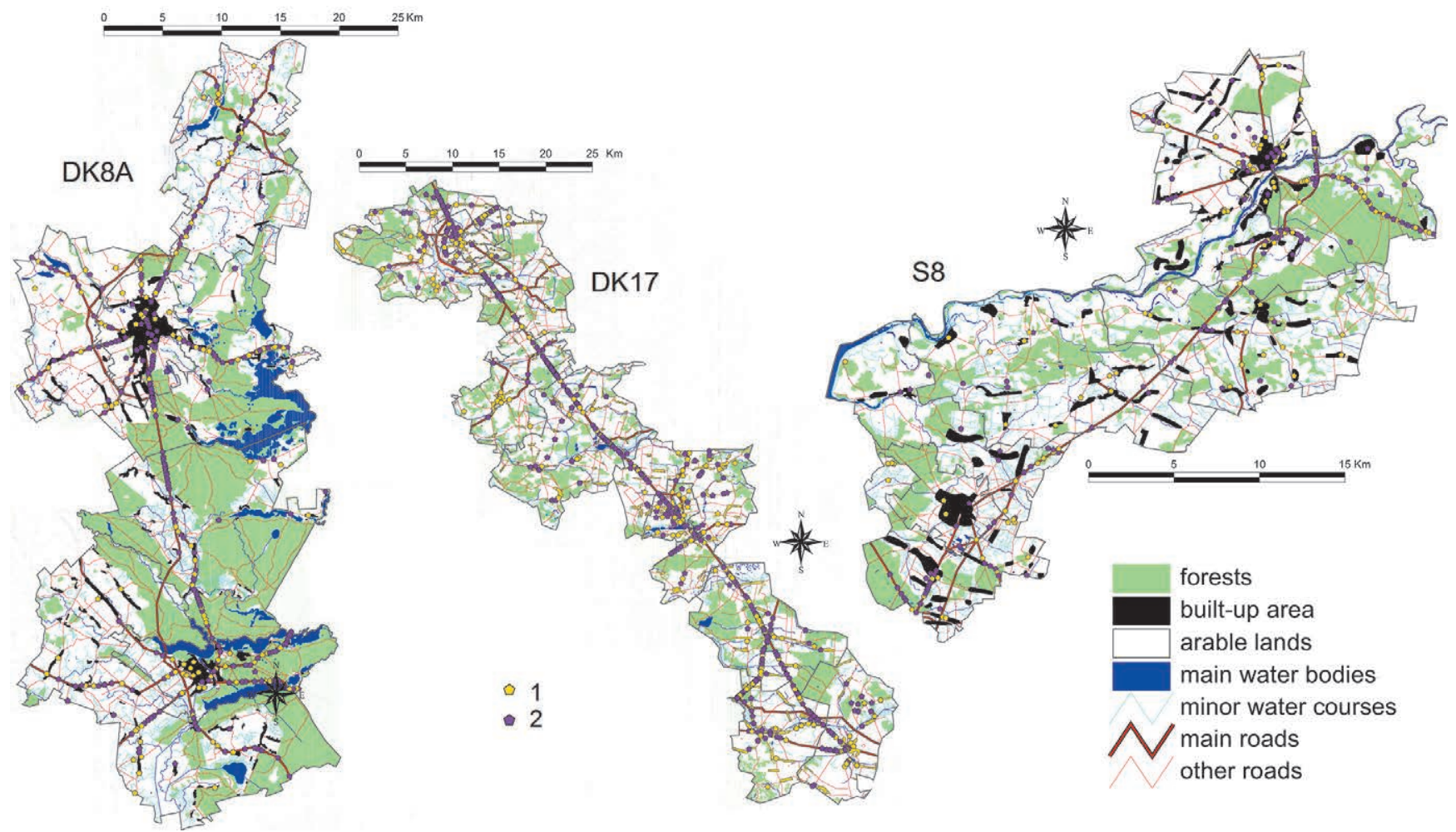

Figure 7 b. Incident location by time of the day. 1 - daytime incidents 2 - night-time incidents Source: own study. 


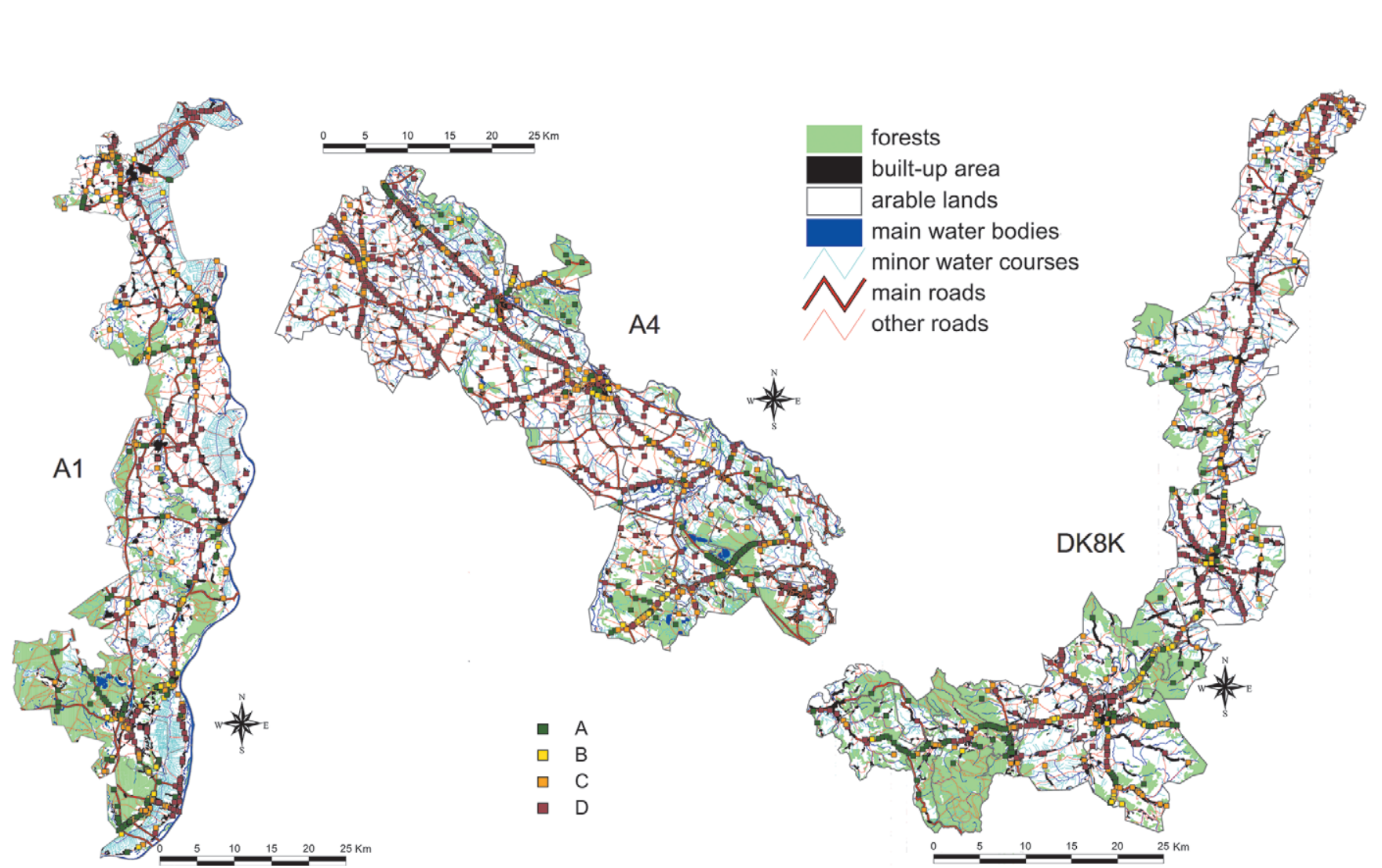

Figure 8a. Location of incidents by distance to forest. A - below $100 \mathrm{~m}$; B - between 100 and $200 \mathrm{~m}$; C - between 200 and $500 \mathrm{~m}$; D - in excess of $500 \mathrm{~m}$ Source: own study. 


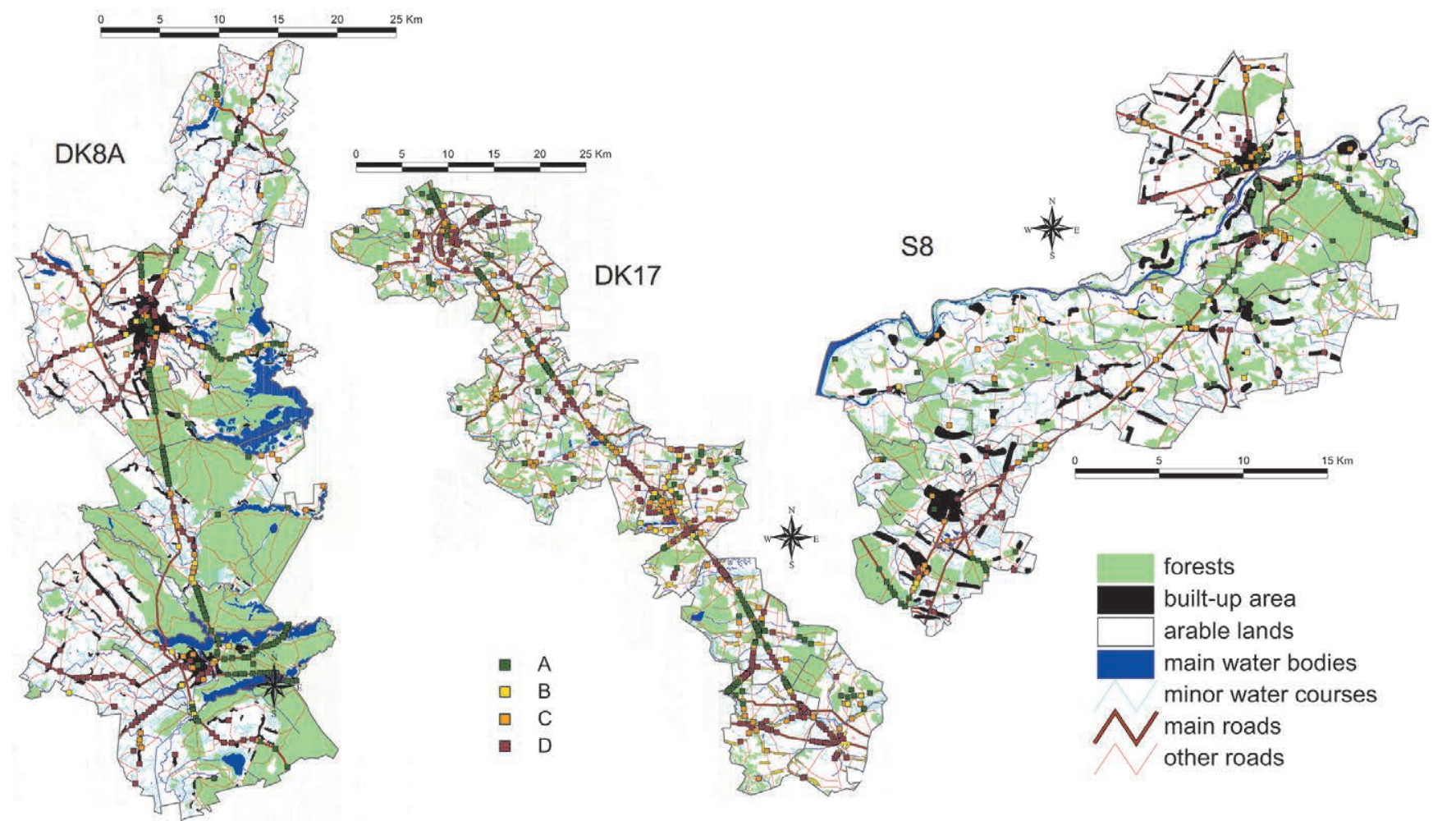

Figure 8b. Location of incidents by distance to forest. A - below $100 \mathrm{~m}$; B - between 100 and $200 \mathrm{~m}$; C - between 200 and $500 \mathrm{~m}$; D - in excess of $500 \mathrm{~m}$ Source: own study. 


\section{Distribution of incidents by distance to forest}

Visual analysis of the data presented in Fig. 8 shows that in areas A1, A4 and DK8K (and, to a lesser extent, also DK17) vast majority of incidents (in absolute terms) occur at least $500 \mathrm{~m}$ away from forest. Translating it into density (number of incidents per $1 \mathrm{~km}$ of road), it turns out that forest and non-forest areas do not differ significantly in these terms, although in each area there is at least one forest complex where density of incident places is visibly higher.

The other two areas are clearly different and each has its own distinctive features. In the area DK8A the majority of important roads have long sections running through the forest. Therefore, the absolute number (and density) of incidents on forest sections or sections situated not farther than $100 \mathrm{~m}$ away from the forest is relatively high and higher than on sections situated at least $500 \mathrm{~m}$ away from the forest.

The area S8 is of a different nature. The majority of incidents are concentrated on road sections running through the forest (and in its vicinity). Also a considerable portion of incidents occurring over $500 \mathrm{~m}$ away from the forest is clearly connected with forest complexes by Lucynów interchange and Bug River valley.

\section{Links between variables affecting the number and place of incidents involving animals}

The analysis of incident places, times of the day and distances from the forest shows there are several general regularities (Fig. 9):

(a) The number of incidents at night is visibly higher than the number of incidents during the day in both general terms and for each category of places and distance from the forest;

(b) The number of incidents occurring 100-200 m away from the forest is the lowest (in absolute terms) compared to other places and slightly lower than it would appear from road section length;

(c) The difference in the number of incidents between day and night is clearly higher outside the built-up areas and within the built-up areas and motorways, and concerns incidents occurring closer than $100 \mathrm{~m}$ and farther than $500 \mathrm{~m}$ from the forest to the greatest extent;

(d) The above relationships are best visible in areas A1, A4 and DK8K, and least noticeable in area S8.

The relation between the time of the day and incidents in and outside the built-up areas requires a more in-depth analysis. Analysis of Figure 9 is not sufficient to formulate unambiguous conclusions. Therefore, the Fisher's two-tailed test was applied. The results are presented in Table 8. 

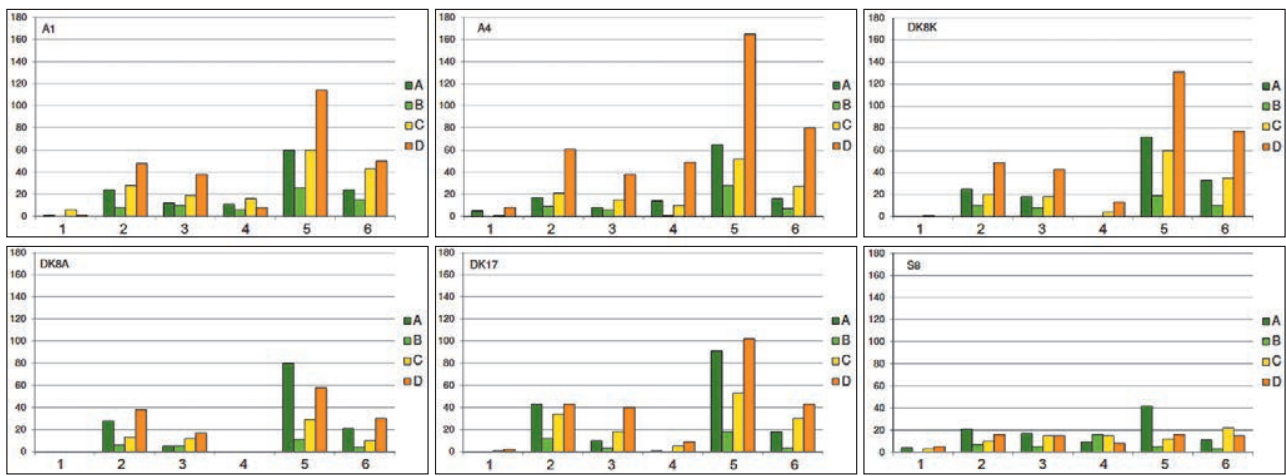

Figure 9. Location of "running over an animal" incidents by distance to forest, time of the day and road type. A - below $100 \mathrm{~m}$; B - between 100 and $200 \mathrm{~m}$; C - between 200 and $500 \mathrm{~m}$; D - in excess of $500 \mathrm{~m}$; 1 - daytime, motorways and expressways; 2 - daytime, other roads outside built-up areas; 3 - daytime, other roads within built-up areas; 4 - night-time, motorways and expressways; 5 - night-time, other roads outside built-up areas; 6 - night-time, other roads within built-up areas

Source: own study.

Table 8. Two-sided $p$ values of Fisher's exact test to analyse the relation between time and place of incidents involving animals. The time is night (between $6 \mathrm{pm}$ and $6 \mathrm{am}$ ) or day. The place is within or outside a built-up area (speed limit above $70 \mathrm{~km} / \mathrm{h}$ )

\begin{tabular}{|c|c|c|c|}
\hline Section & p & chi $^{2}$ & Relationship \\
\hline A1 & 0.0079 & 7.4612 & YES \\
\hline A4 & 0.1088 & 2.7372 & \\
\hline DK8K & 0.0071 & 7.7710 & YES \\
\hline DK17 & 0.0169 & 6.0210 & YES \\
\hline DK8A & 0.3838 & 0.8123 & \\
\hline S8 & 0.0274 & 5.0463 & YES \\
\hline
\end{tabular}

Source: own study.

Test results show that in the majority of areas (i.e. A1, DK8K, DK17 and S8) there are more incidents in than outside the built-up areas during the day compared to the expected value. At night there are visibly less incidents within the built-up areas and outside the built-up areas there are much more incidents compared to the expected values. Such a visible relationship between the time of the day and incident place was not established for areas A4 and DK8A.

\section{Conclusions}

The above analysis of occurrence of incidents involving animals (in category "running over an animal") is not the first one in Polish literature, but the most thorough compared to previous 
publications. Although it concerns only selected areas and road sections, its results allow making further generalisations.

The analysis has some limitations, though, they result primarily from the nature of input data. First of all, the characteristics of incidents in the SEWIK database make it impossible to unambiguously state whether an incident was caused by a wild, feral or farm animal/pet. Therefore, many analyses include a category "incidents outside the built-up areas at night" which assumes that in the majority of cases the incidents were caused by wild animals. In the case of incidents during the day, especially within the built-up areas, it can be assumed that at least a considerable part of incidents involved feral or farm animals/pets. Another limitation connected with data quality results from the fact that the SEWIK database only covers registered incidents which probably constitute only $20-30 \%$ of all collisions and incidents "running over an animal", which has been repeatedly mentioned in literature. Moreover, available data obviously do not include the majority of incidents involving medium-sized and small mammals and other small animals.

Despite the above limitations, although the approach adopted for the analysis does not yield a fully reliable estimation of the number of incidents involving wild animals, it allows relative comparative evaluation of the barrier role of individual sections of roads and migration routes (wildlife corridors) within landscape.

Analysis of data shows that between 2006 and 2012 the number and share of incidents involving animals increased systematically. The nature of this phenomenon is unclear, but several reasons behind it, occurring separately or jointly, are known. They are:

- high increase in the population of many large mammal species, which results in a higher number of incidents with the same frequency of attempts to cross roads;

- animals getting used to road traffic, especially on less busy roads, which results in an increase in the frequency of attempts to cross the road;

- increase in road traffic intensity without greater "deterrent effect", which results in a higher number of collisions with the same frequency of attempts to cross roads.

Analyses also show that although new roads (motorways and expressways) do not significantly increase the values of formal landscape fragmentation indicators, they constitute considerable physical barriers. It is proven on the one hand by visibly lower number and density of incidents on those routes compared to other roads (per $1 \mathrm{~km}$ ), and on the other hand by concentration of incidents near interchanges (especially in forest areas), where animals find is easy to get on motorways.

Data analysis shows that, at least for selected test areas, there is no simple relation between the degree of landscape fragmentation, population and distribution of forest patches on the one hand and the total number of incidents and their distribution in space on the other hand. It also seems that the relationship is much more complex and includes inter alia:

- impact of general synanthropisation of landscape, as exampled by exceptionally low number of incidents in the central part of area S8 not only on expressway, aby also on local roads;

- crossing large forest complexes which extend by far beyond the test areas, as exemplified by a considerable number of incidents along Augustów-Suwałki section (area DK8A) and on the road No 62 in Wyszków gmina (area S8), although the roads differ considerably in terms of width and traffic intensity;

- presence of a dense network of rivers and canals with large areas of meadows and tree-covered areas in the neighbourhood, as exemplified by a high number of incidents involving animals on the north-western section of road A4 compared to other sections of the road, even those running through forests; 
- absence of barriers other than roads, which results in general permeability of landscape and in consequence generates similar number (and density) of incidents in and outside forest areas, which is particularly visible in areas DK8K and DK17.

Apart from the above general discussion, the material under analysis allows formulating several more specific conclusions. The most important conclusions are as follows:

- incidents involving animals occur mainly late in the evening and at night;

- incidents occurring up to $100 \mathrm{~m}$ away from the forest are more frequent than incidents occurring 100-200 m away from the forest, which may prove that animals have preferences as to their routes;

- incidents within the built-up areas, especially during the day, have a different seasonal rhythm and there are no distinct periods of minimums and maximums, which may indirectly prove that these incidents involve animals other than wild ungulates.

\section{References}

Borowska S., 2008. Kolizje z dzikimi zwierzętami na drogach w Polsce. Master's thesis, Faculty of Civil and Environmental Engineering, Warsaw: Warsaw University of Life Sciences.

Borowska S., 2010. Report Śmiertelność zwierząt na drogach w Polsce. zwolnij.wwf.pl/dokumenty/ raport.pdf [10 November 2014].

Czerniak A., Tyburski Ł., 2011. Zdarzenia drogowe z udziałem zwierzyny. Infrastruktura i Ekologia Terenów Wiejskich, 2, pp. 275-283.

Forman R. T. T., Alexander L.E., 1998. Roads and Their Major Ecological Effects, Annu. Rev. Ecol. Syst., 29, pp. 207-231.

Forman R.T.T., Sperling D., Bissonette J., Clevenger A.P., Cutshall C., Dale V., Fahrig L., France R., Goldman C., Heanue K., Jones J., Swanson F., Turrentine T., Winter T., 2009. Road Ecology. Alliance of Associations Polish Green Network.

Jaeger J.A.G., Soukup T., Madriñán L.F., Schwick C., Kienast F., 2011. Landscape fragmentation in Europe. EEA Report No.2/2011, 87 pp.

Jędrzejewska B., Jędrzejewski W., 2008. Wpływ fragmentacji środowiska na populacje zwierząt i ochrona łączności ekologicznej. [in:] W. Jędrzejewski, D. Ławreszuk (eds.), Ochrona łączności ekologicznej w Polsce. Białowieża: Mammal Research Institute of the Polish Academy of Sciences, pp. 13-18.

Jędrzejewski, W., Nowak, S., Kurek, R., Mysłajek, R.W., Stachura, K., Zawadzka, B., 2006. Zwierzęta a drogi. Metody ograniczania negatywnego wplywu dróg na populację dzikich zwierząt. Białowieża: Mammal Research Institute of the Polish Academy of Sciences.

Jędrzejewski W., Nowak S., Stachura K., Skierczyński M., Mysłajek R.W., Niedziałkowski K., Jędrzejewska B., Wójcik J.M., Zalewska H., Pilot M., 2005. Projekt korytarzy ekologicznych taczacych Europejska sieć Natura 2000 w Polsce. Study commissioned by the Ministry of the Environment under Phare PL0105.02. Białowieża: Mammal Research Institute of the Polish Academy of Sciences.

Kurek R., 2010a. Poradnik projektowania przejść dla zwierząt i działań ograniczających śmiertelność fauny przy drogach. Workshop for All Beings.

Kurek R., 2010b. Zwierzęta i drogi. Ochrona zwierzat przy drogach szybkiego ruchu w Polsce. Workshop for All Beings. 
McGarigal K., Marks B., 1995. FRAGSTATS: Spatial Pattern Analysis Program for Quantifying Landscape Structure. Gen. Tech. Report PNW-GTR-351, USDA Forest Service, Portland: Pacific Northwest Research Station.

Morawska A., Żelazo J., 2008. Oddziaływanie dróg na środowisko i rola postępowania w sprawie OOS na przykładzie planowanej drogi krajowej. Przegląd Naukowy Inżynieria i Kształtowanie Środowiska, XVII, 4 (42), pp. 95-109.

Prognoza oddziaływania na środowisko skutków realizacji Programu Budowy Dróg Krajowych na lata 2011 - 2015 (Environmental Impact Assessment of the Programme for the Construction of National Roads for 2011-2015), 2011. Warsaw: GDDKiA.

Richling A., Solon J., 2011. Ekologia krajobrazu. Warsaw: Wyd. Naukowe PWN.

Tyburski Ł., Czerniak A., 2012. Inwentaryzacja zwierzat padtych na drogach $w$ wyniku kolizji z pojazdami. Infrastruktura i Ekologia Terenów Wiejskich, 3.1, pp. 145-154.

Tyburski Ł., Czerniak A., Kaczmarek A., Kanas K., Górna M., 2012. Zdarzenia drogowe z udziatem zwierzyny w okresie zimowym. Prace Komisji Nauk Rolniczych i Komisji Nauk Leśnych PTPN, vol. 103, pp. 103-111. 